\title{
Effect of prey availability on growth-rate trajectories of an aquatic predator, the viperine snake Natrix maura
}

\author{
Aikaterini Filippakopoulou ${ }^{1}$, Xavier Santos ${ }^{2,}$, Mónica Feriche ${ }^{3}$, Juan M. Pleguezuelos ${ }^{3}$, Gustavo A. Llorente ${ }^{1}$ \\ ${ }^{1}$ Departament de Biologia Animal, Universitat de Barcelona, Barcelona, Spain. \\ ${ }^{2} \mathrm{CIBIO} / \mathrm{InBIO}$, Centro de Investigação em Biodiversidade e Recursos Genéticos da Universidade do Porto, Vairão, Portugal. \\ ${ }^{3}$ Departamento de Zoología, Universidad de Granada, Granada, Spain. \\ * Correspondence: CIBIO/InBIO, Centro de Investigação em Biodiversidade e Recursos Genéticos, Universidade do Porto, \\ 4485-661 Vairão, Portugal. Phone: +351 252660400, Fax: +351 252661780, E-mail: xsantossantiro@gmail.com
}

Received: 17 January 2014; received in revised form: 29 April 2014; accepted: 3 May 2015.

The energy gained by an organism is used for maintenance, growth and reproduction. In habitats with limited resources, these processes compete for available energy and may induce intraspecific variation in body condition, growth trajectories and reproductive output. We tested the hypothesis that populations exposed to higher food availability are able to grow faster, and attain larger body sizes in the viperine snake (Natrix maura). We estimated snake age by counting growth lines in the skull's ectopterygoid bone, and compared body size growth curves from three Iberian populations exposed to temporal variation of food resources availability. In the three localities, and in males and females, the growth curves followed a quadratic function that tended to an asymptotic value as growth slowed down. Growth curves showed slower growth rates and an early asymptote for males, in agreement with the reverse sexual dimorphism in body size of this species. We also detected interpopulational differences, with the Ebro Delta population exhibiting slower growth rates and smaller asymptotic body size in both sexes. This population inhabits rice fields with an artificial waterflow cycle, a condition that implies a shorter period of prey availability for snakes, compared to the other two populations, where prey is available for longer periods of time. Moreover, high proportion of snakes with tail breakage in this population indicated high predation pressure. These environmental conditions suggest that food availability and predation pressure may be concurrently acting to produce smaller N. maura at the Ebro Delta than at the other two populations.

Key words: energy allocation; life-history traits; Natrix maura; quadratic regression; skeletochronology; snake.

Efecto de la disponibilidad de presas en las trayectorias de crecimiento de un depredador acuático, la culebra viperina Natrix maura. Los organismos invierten su energía en mantenimiento, crecimiento y reproducción. En hábitats con una disponibilidad de recursos limitada, estos procesos compiten por la energía disponible y pueden inducir variación intraespecífica en la condición corporal, trayectorias de crecimiento y rendimiento reproductivo. Hemos comprobado en la culebra viperina (Natrix maura) la hipótesis de que las poblaciones con una mayor disponibilidad de recursos son capaces de crecer más rápido y alcanzar tamańos corporales mayores. En este estudio estimamos la edad de los individuos contando las líneas de crecimiento en el hueso pterigoideo del cráneo, y comparamos las curvas de crecimiento corporal de tres poblaciones ibéricas expuestas a variación temporal en la disponibilidad de recursos alimentarios. En las tres localidades, y tanto en machos como en hembras, las curvas de crecimiento siguieron una función cuadrática con tendencia a valores asintóticos a medida que el crecimiento disminuía. Las curvas de crecimiento mostraron tasas menores y una asíntota más temprana en machos, de acuerdo con el dimorfismo sexual reverso en tamańo corporal en esta especie. Asimismo detectamos diferencias interpoblacionales, con la población del delta del Ebro mostrando tasas de crecimiento menores y un menor tamaño corporal asintótico en los dos sexos. Esta población ocupa arrozales con ciclos artificiales de disponibilidad de agua, una condición que implica un periodo más corto de disponibilidad de presas en comparación con las otras dos poblaciones, donde las presas están dis- 
ponibles durante periodos de tiempo más prolongados. Por otra parte, una mayor proporción de individuos con colas partidas sugiere una mayor presión de depredación. Estas condiciones ambientales sugieren que la disponibilidad de alimento y la presión de depredación pueden estar actuando simultáneamente produciendo $N$. maura de un tamaño menor en el Delta del Ebro que en las otras dos poblaciones.

Key words: capacidades cognitivas; navegación; orientación; Rumanía; señales visuales; Tulcea.

Organisms have the capacity to extract energy from their environment, process that energy, and allocate it to maintenance and production (CONGDON et al., 1982, 2001; MCNAB, 2002). Energy used for maintenance covers two targets: i) standard maintenance, i.e. the basal energetic cost of living, and ii) activity maintenance, i.e. the energy required for activities such as digestion and locomotion. The energy allocated to production supports growth and reproduction. For many organisms, most energy is used for maintenance and far less is used for production (DuRAnT et al., 2007). For example, nonavian reptiles spend $80 \%$ of their energy budget on maintenance and $20 \%$ on production (CONGDON et al., 1982).

Resources available in the environment are often limited, and tasks such as maintenance, growth, and reproduction may compete for energy to optimise their respective output values (LESSELLS, 1991; STEARNS, 1992). Consequently, the allocation of energy to one particular process could occur at the expense of others (STEARNS, 1976, 1989; SHINE, 1980). Foragers occasionally face periods in which food is scarce or even non-existent, and stress caused by a reduction in prey availability may constrain the rate of energy intake (REZNICK et al., 1990). In these situations, organisms may allocate less energy to growth and reproduction, and more to maintenance, in order to increase their chances of survival (FORSMAN \& LINDELL, 1991).
Snakes are an adequate group for studying a variety of biological and ecological aspects related to how the partition of energy to different competing needs is affected by resource levels (FORSMAN \& LiNDELL, 1996; SHINE et al., 2002; BОВACK, 2003). Most female snakes are capital breeders, which accumulate body reserves for long periods before reproduction for fuelling vitellogenesis (BONNET et al., 1994; NAUlleaU \& BonNET, 1996). They continue to grow after attaining reproductive status (ANDREWS, 1982), and therefore adult body size and reproductive output can interact and vary depending on the local conditions of prey availability (AubreT \& SHINE, 2007). How food availability drives some snake reproductive parameters (i.e. reproductive outputs) has been widely studied in snakes (reviewed in SHINE, 2003). In contrast, few studies have examined the effects of food availability on snakes' growth trajectories, due to the inherent complexity of long-term monitoring studies. Snakes show a high degree of ontogenetic plasticity, and environmental factors impacting early life stages can modify later growth rates (MADSEN \& SHINE, 1993; O'STEEN, 1998; Aubret et al., 2004). In this context, we hypothesize that intraspecific differences in growth trajectories and / or reproductive output will appear among populations under different availability of food resources, ultimately affecting the maximum body size attained by snakes. 
We examined this hypothesis within the viperine snake Natrix maura, an aquatic predator that feeds on a wide range of prey types (SANTOS, 2004) and whose diet is modulated by the availability of aquatic prey (SANTOS et $a l ., 2000)$. In this species, seasonal variation in prey availability influenced the amount of energy stored in several body compartments, and affected reproductive output (SANTOS \& Llorente, 2004; SANTOS et al., 2007). When prey were scarce, $N$. maura delayed its reproductive timing until females obtained sufficient reserves (SANTOS et al., 2005). These results highlight how food availability may influence energy-demanding processes in this aquatic snake.

In this study, we examined how preyavailability regimes may affect intraspecific growth patterns and offspring size in $N$. maura. We hypothesized that populations under different prey-availability regimes differ in their growth-rate responses due to conflicts in energy allocation between energydemanding processes (e.g. growth and reproduction). Natrix maura shows strong sexual dimorphism in body size, as females are larger and achieve sexual maturity at larger sizes than males (SANTOS, 2004), a feature that allows grow-rate trajectories to be compared intersexually. To analyse inter-population and sexual differences in growth rates, we measured the growth trajectories of three $N$. maura populations inhabiting two natural habitats, a wetland and a river, and one artificial habitat with high food availability, a fish farm. We expect faster growth rates in the larger sex (females), and in populations that experience longer periods of prey availability irrespective of sex.

\section{MATERIALS AND METHODS}

\section{Study area}

Natrix maura is a medium-sized aquatic snake that inhabits Western Mediterranean natural (ponds, rivers, marshes, streams) and artificial water bodies (SANTOS, 2004). We examined $168 N$. maura specimens (in collections in the Animal Biology Departments at the Universities of Barcelona and Granada), from three Iberian populations with different environmental characteristics. Each locality was sampled to measure prey availability for viperine snakes, as described below.

The Ebro Delta (ca. 0o 45’ E, 40 $42^{\prime} \mathrm{N}$, $5 \mathrm{~m}$ above sea level) is a wetland partially covered by rice fields. Rice-crop cycles cause disturbances to aquatic species due to changes in the regime of water flow. Canals and rice fields overflow from April to October, when they dry up until the following April. We studied 93 individuals of $N$. maura captured in 1990 and 1991. The snake's diet at this population was composed of the green frog Pelophylax perezi and two fish species Cyprinus carpio and Gambussia holbrooki (SANTOS et al., 2000). Prey availability was estimated by sampling 4-6 canals monthly, from April to November 1991, as this is the habitat most frequently used by $N$. maura for foraging (SANTOS \& LlORENTE, 1998). Samples were taken using a $2 \mathrm{~m}$ hand net (60 x $60 \mathrm{~cm}, 1.8 \mathrm{~mm}$ mesh). The net was positioned near the bottom of the canal, and moved unidirectionally along 10 meter transects, collecting fish and other prey types. This method efficiently samples all vertebrates, except large fish (FASOLA, 1986), but 
these specimens / taxa are not consumed by the viperine snake (SANTOS \& LLORENTE, 1998). Collected prey specimens were identified to the species level, measured ( $\pm 1 \mathrm{~mm}$ ), and their dry weight mass calculated by the linear regressions of dry mass on body length (biomass; GonZÁLEZ-Solís et al., 1996). We then calculated $N$. maura's prey biomass per square meter of canal to obtain monthly variation in available biomass in the habitat.

The Matarranya River (ca. $0^{\circ} 12^{\prime} \mathrm{E}, 41^{\circ} 13^{\prime} \mathrm{N}$, $508 \mathrm{~m}$ above sea level) has a typical Mediterranean water regime, with seasonal flow changes related to rainfall periods; the highest flows occur in spring and autumn, and the lowest in summer. We studied 30 female $N$. maura individuals collected between 1984 and 1986 (the absence of males precluded a sexual comparison at this population). The snake's diet was composed of P. perezi, and four fish species, Barbus graellsii, Chondrostoma miegii, Squalius cephalus and Salaria fluviatilis (SANTOS et al., 2006). Fish were sampled every two months from 1984 to 1986 . Surveys were performed with standard electrofishing equipment (device of direct current, $4500 \mathrm{~W}$ generator, working voltage of 300-400 V, intensity of 1.5-2.0 A, and a $30 \mathrm{~cm}$ anode), efficient for estimating fish densities (BoHLin et al., 1989). Electrofishing was conducted three times in river sections ca. $100 \mathrm{~m}$ long previously confined with nets. Captured fish were identified to the species level, counted, weighed $( \pm$ $0.1 \mathrm{~g})$, measured $( \pm 1 \mathrm{~mm})$, and released at the localities they were caught. Abundance estimates were made using the Zippin (1958) method and the CAPTURE software (White et al., 1978).
Riofrío ( $4^{\circ} 10^{\prime} \mathrm{W}, 37^{\circ} 10^{\prime} \mathrm{N}, 485 \mathrm{~m}$ above sea level) is a fish farm in the south of the Iberian Peninsula devoted to raising Oncorhynchus mykiss. We studied $45 \mathrm{~N}$. maura collected between 1988 and 1990; their diet was exclusively composed by fish (J.M. Pleguezuelos, unpublished data). Data on number of fish per water volume (prey availability) and their average size were provided by fish farmers. We used this information to calculate fish wet mass per square meter of water.

No snakes were killed for this study. Snout-vent length (SVL) of individuals at the time of collection was available for the Ebro Delta and the Matarranya River populations. In the Riofrío fish farm, snakes were killed by fish farmers to reduce predation upon fish, and we obtained body-size measures from preserved specimens. The procedure to estimate fresh body size of the snakes is explained below.

In most of its Iberian range, $N$. maura becomes active in March (JAÉN \& PÉREZMellado, 1989; Santos \& Llorente, 2001). Although N. maura may be occasionally active in sunny winter days (SANTOS \& LlORENTE, 2001; MalKMUS, 2008), experimental studies demonstrated that digestion stops and prey are regurgitated when body temperature falls below $10^{\circ} \mathrm{C}$ (HaILEY \& DAVIES, 1987a). Thus, snakes are typically active in water temperatures above 13.0$17.8^{\circ} \mathrm{C}$ in Iberia (HAILEY et al., 1982; JAÉN \& PÉreZ-Mellado, 1989). At the Ebro Delta, field observations indicate that $N$. maura starts its activity when air temperature is ca. $12^{\circ} \mathrm{C}$ (authors' personal observations; SANTOS, 2004), thus, we assumed that snakes were not active below this temperature. 
To determine the foraging period for each population, we collated temporal variation in prey availability and mean air temperatures, the latter obtained from the Agencia Estatal de Meteorología. As explained previously, food availability was measured with different methods at each population. However, our objective was not to compare the amount of food availability among the sites, but to know when prey were available at each study site. We assumed that foraging activity started in all three study sites when prey were available and air temperature was higher than $12^{\circ} \mathrm{C}$.

\section{Snake body size and age}

We measured the snout-vent length (SVL) of freshly caught individuals from the Ebro Delta and Matarranya River populations using a cord placed along the mid-dorsal line of the body. In general, preserved animals (in 75\% ethanol) from the Riofrío population had shrunk. To compare SVL measurements from the three populations, we estimated the SVL of Riofrío at the time of collection following the procedures outlined by SANTOS et al. (2011).

We estimated the snakes' ages by skeletochronology (CASTANET et al., 1977). Previous studies in $N$. maura demonstrated that the ectopterygoid is a suitable flat bone to observe growth marks (HAILEY \& DAVIES, 1987a). Likewise, WAYE \& GREGORY (1998) detected little variation in the number of layer counts between the caudal vertebrae and the ectopterygoid in Thamnophis spp. garter snakes from Canada; 20 out 37 (54\%) of the animals examined by these authors had the same number of growth layers in both bones, and only four individuals (10.8\%) showed more layers in the ectopterygoid bone than in the caudal vertebrae (maximum difference was two layers).

We removed the right ectopterygoid from 168 individuals of $N$. maura. To facilitate skeletochronology procedures, bones were photographed with an optic microscope (Leitz Dialux 20) at 40 X magnification. Each photograph was analysed carefully, and growth marks counted following procedures described in Peabody (1961), i.e. each dense line in the bone corresponded to an active osteogenesis period followed by low or lack of osteogenesis (no visible marks). To prevent inaccurate interpretations influenced by bone size (WAYE \& GREGORY, 1998), we carried out a blind test: a code was assigned to each bone, and growth mark numbers were not assigned to specific bones until all readings were completed. Additionally, we counted the number of layers on caudal vertebrae of 10 randomly selected $N$. maura specimens, following procedures by WAYE \& GREGORY (1998). Vertebrae were decalcified with $4 \%$ formaldehyde and 3\% nitric acid during $1 \mathrm{~h} 45$ min, and sections of $14 \mu \mathrm{m}$ thickness were made with a cryomicrotome and stained with 0.05 Ehrlich's Haematoxilyn. The number of layers on caudal vertebrae and ectopterygoid bones were identical for each of the ten individuals examined (Fig. S1), supporting the reliability of our procedure for aging snakes.

\section{Data analysis}

After checking that body sizes were evenly distributed throughout the entire age range, we verified whether SVL significantly differed between populations using Analysis of the Variance (ANOVA). Male and female 

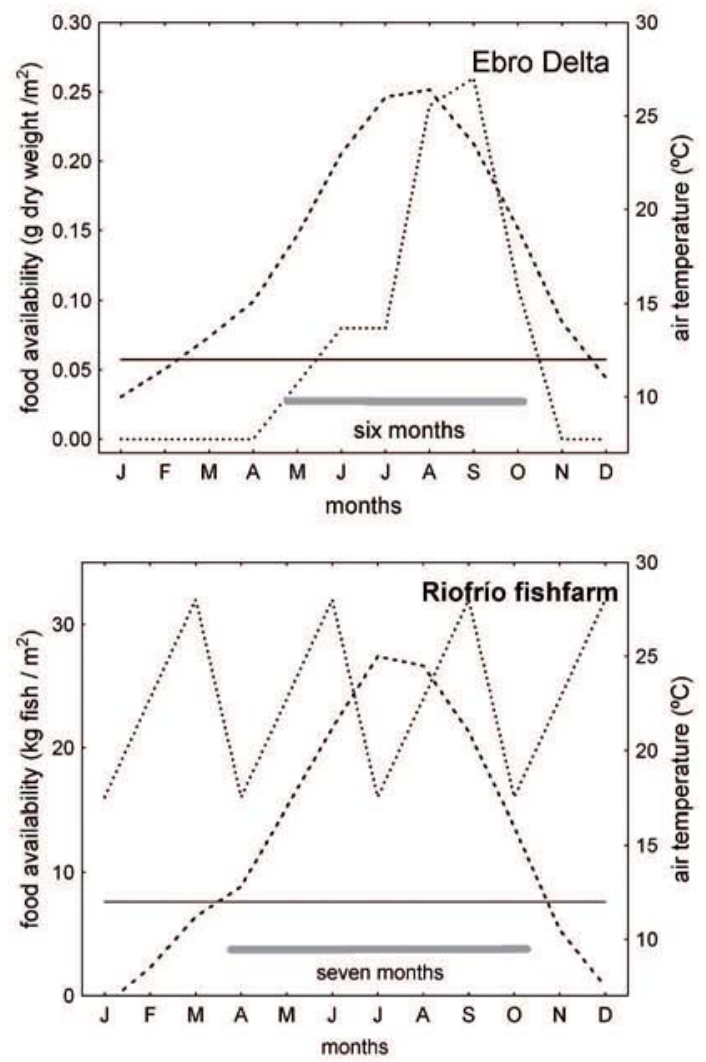

$N$. maura were analysed separately because of sexual dimorphism in body size. To estimate growth curves, we conducted quadratic and logistic regressions between the estimated age and SVL for both sexes in the three populations with STATISTICA 8.0 (STATSOFT, 2007) and MatLab 7.0 (MATHWorKS, 1996) softwares. Once we confirmed our data fitted a quadratic regression function, we performed intersexual and interpopulation comparisons for both sexes in growth trajectories.

Sexual and interpopulation differences in growth rates were tested by comparing line slopes using SMATR Software (FALSTER et al., 2006). This program adjusts comparative categories to a linear regression model and conducts two types of tests: the standardised

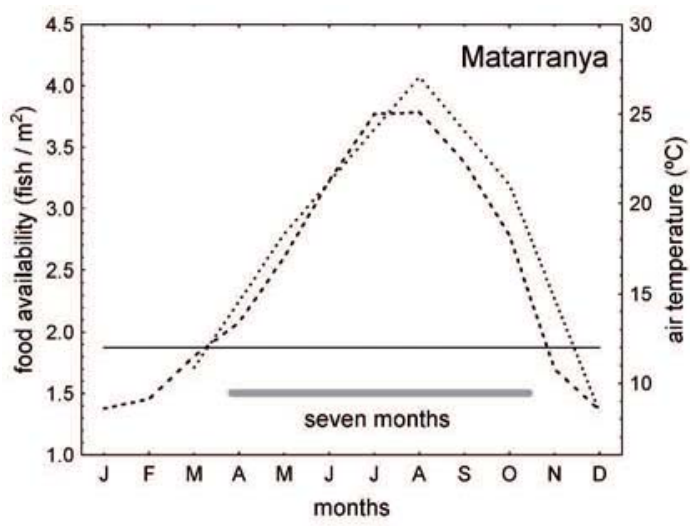

Figure 1: Temporal variation in food availability (dotted line) and environmental temperature (dashed line) for the three populations studied. To establish the foraging period for each population (grey line), we assumed that foraging activity started when prey availability was different from zero and the environmental temperature was higher than $12^{\circ} \mathrm{C}$ (solid black line).

major axis test (SMA), which reports growthrate differences, and the Wald test, which reports elevation differences that indicate different body sizes at birth. Finally, the maximum of each quadratic function was calculated to find the asymptotic growth point. This point indicates the age at which growth slows, and the maximum size reached by the study population.

\section{RESULTS}

\section{Estimates of food-availability}

Comparisons of temporal variation in air temperatures and food availability at each population (Fig. 1) suggested that the fora- 
ging period estimates is six months for the Ebro Delta population, and slightly longer than seven months at the Matarranya River and the Riofrío fish farm. In the Ebro Delta, rice-field farmers regulate the water flow to keep the rice fields dry until the end of April, and consequently prey are not available for water snakes until this period (SANTOS et al., 2000). At the Riofrío fish farm, fish are available the entire year, and food availability varies due to fish cohorts replacement every three months. In summary, as food resources were available all year at Matarranya and Riofrío, foraging activity of viperine snakes in these localities is likely regulated by environmental temperature.

\section{Age estimates and growth curves}

The estimated age of $N$. maura, calculated by counting the ectopterygoid growth marks ranged from 0 to 22 years (the oldest snake was a female from the Matarranya River, $595 \mathrm{~mm} \mathrm{SVL}$ ). The relationship between estimated age and SVL was adjusted in all cases to quadratic and logistic distributions, with a goodness of fit ca. $80 \%$ (Table 1). Because both adjustments had a similar coefficient of determination, we chose the quadratic regression, which allowed us to calculate the asymptotic curve more easily.

The equations of the quadratic regressions indicated that the growth of males from the Ebro Delta and Riofrío slowed down at the same estimated age (18.9 and 18.7 years respectively; Table 1 ), whereas the asymptotic point for Ebro Delta females was 19.7 years. This finding suggests that females continue growing for a longer period than males. Females from Matarranya and Riofrío apparently exhibited linear growth; this could be an artefact as some individuals reached the largest SVL measured in this study. Thus, to estimate the maximum size attained by females in the Matarranya and Riofrío populations, we assumed 20 years as the asymptotic point, based in the maximum age registered for females in the Ebro Delta and southeastern Iberia (Hailey \& DAVIES, 1987b).

Table 1: Quadratic and logistic goodness of fit $\left(\mathrm{R}^{2}\right)$, and quadratic equation of the relationship between age and body size in Natrix maura males and females at the three study populations. Using the quadratic equation, we calculated the age at which growth slows downs (asymptotic point) as well as the maximum body size reached (snout-vent length, SVL). The asymptotic points for females from the Matarranya and Riofrío populations (in brackets) were estimated following the procedure detailed in the text.

\begin{tabular}{|c|c|c|c|c|c|}
\hline Group & $\begin{array}{c}\mathrm{R}^{2} \text { logistic } \\
\text { model }\end{array}$ & $\begin{array}{l}\mathrm{R}^{2} \text { quadratic } \\
\text { model }\end{array}$ & $\begin{array}{l}\text { Quadratic } \\
\text { equation }\end{array}$ & $\begin{array}{c}\text { Age } \\
\text { (years) }\end{array}$ & $\underset{(\mathrm{mm})}{\operatorname{Max} \text { SVL }}$ \\
\hline đ Ebro Delta & 0.8173 & 0.8165 & $S V L=143.55+28.14 x-0.74 x^{2}$ & 18.9 & 410.0 \\
\hline 아으 Delta & 0.8689 & 0.8738 & $S V L=127.70+37.37 x-0.95 x^{2}$ & 19.7 & 496.2 \\
\hline o Matarranya & 0.8569 & 0.8527 & $S V L=188.39+25.61 \mathrm{x}-0.11 \mathrm{x}^{2}$ & (20) & 656.59 \\
\hline ô Riofrío & 0.8948 & 0.8923 & $S V L=178.19+32.27 x-0.86 x^{2}$ & 18.7 & 480.0 \\
\hline q Riofrío & 0.7782 & 0.7781 & $S V L=177.55+33.44 x-0.59 x^{2}$ & (20) & 610.35 \\
\hline
\end{tabular}


At the Ebro Delta, females were larger than males of the same age (ANOVA, $\mathrm{F}_{1,91}=10.9$, $P=0.001)$. As stated, the asymptotic points of the same age differed by about one year, and at this age females had a much larger SVL than males (496 and $410 \mathrm{~mm}$, respectively). Predicted growth rates were $14.28 \mathrm{~mm}$ / year for males and $18.08 \mathrm{~mm} \mathrm{/} \mathrm{year} \mathrm{for} \mathrm{females.}$ Consequently, the slopes of the regression lines differed significantly (SMA test, $\mathrm{T}=7.5$, $P=0.007$; Fig. 2).

Ebro Delta females were smaller than those from Riofrío (ANOVA, $\mathrm{F}_{1,60}=7.53, P=0.007$ ) and Matarranya $\left(\mathrm{F}_{1,68}=13.04, P=0.0005\right)$, but females from Matarranya and Riofrío had similar body sizes $\left(\mathrm{F}_{1,50}=0.61, P=0.4\right)$. We assumed that the asymptotic point of the females did not differ among the three populations (19.7 years), and at this age females from Riofrío and the Matarranya had a much larger SVL than those from the Ebro Delta (609, 650, and $496 \mathrm{~mm}$, respectively; Fig. 3). The predicted growth rate for Riofrío females was $22.80 \mathrm{~mm}$ / year, that is $4.72 \mathrm{~mm} /$ year higher than for the Ebro Delta females. The slopes of the regression lines did

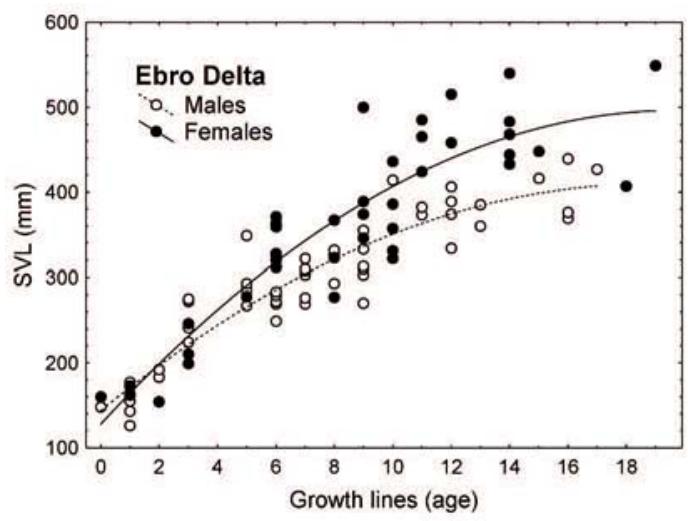

Figure 2: Relationship between age and body size (snout-vent length, SVL) for Natrix maura males (empty circles and dotted line) and females (closed circles and solid line) in the Ebro Delta.

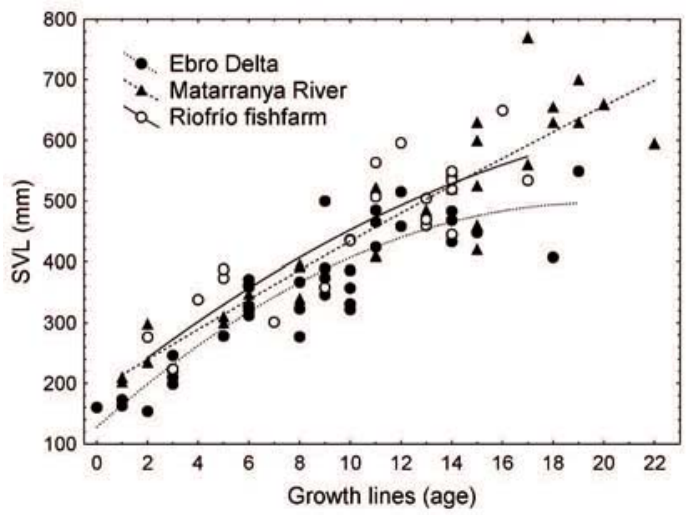

Figure 3: Relationship between age and body size (snout-vent length, SVL) for Natrix maura females in the Ebro Delta (closed circle and dotted line), Matarranya River (triangles and dashed line) and Riofrío (empty circles and solid line).

not differ significantly in any of the three pairwise comparisons (Table 2, SMA test), perhaps because of the small sample sizes available for this test. However, we found significant differences in the elevation of the regression lines in Ebro Delta - Riofrío, and Ebro Delta Matarranya (Table 2, Wald test), a finding consistent with the observed differences in annual growth rates.

Similarly, Riofrío males were larger than those from Ebro Delta (ANOVA, $F_{1,74}=14.05$, $P=0.0003)$. The asymptotic point did not differ between the two populations (see above), and at that this point, Riofrío males had a much larger SVL than those from the Ebro Delta (480 and $410 \mathrm{~mm}$, respectively; Fig. 4). Predicted growth rate in Riofrío males was $17.48 \mathrm{~mm} /$ year, $3.20 \mathrm{~mm} /$ year higher than in the Ebro Delta males. Although the slopes of the regression lines did not differ significantly (SMA test, $\mathrm{T}=0.130$, $P=0.71$ ), their elevations did (Wald test Stat = 124.9, $P=0.0001$ ) (Fig. 4) in agreement with variation in annual growth rate. 
Table 2: Interpopulation comparisons of slopes (SMA test) and asymptotes (Wald test) calculated from the age versus body size quadratic equation in female Natrix maura in three populations within the Iberian Peninsula.

\begin{tabular}{lcc}
\hline \hline Compared groups & $\begin{array}{c}\text { Slope comparisons } \\
\text { (SMA test) }\end{array}$ & $\begin{array}{c}\text { Asymptote comparisons } \\
\text { (Wald Test) }\end{array}$ \\
\hline Ebro Delta and Riofrío & $\mathrm{T}=0.5, P=0.4$ & Stat $=18.8, P=0.003$ \\
Ebro Delta and Matarranya & $\mathrm{T}=0.4, P=0.5$ & Stat $=15.3, P=0.02$ \\
Riofrío and Matarranya & $\mathrm{T}=0.4, P=0.5$ & Stat $=10.58, P=0.44$ \\
\hline
\end{tabular}

\section{Reproductive traits}

The hatchlings from the Ebro Delta were smaller $(151.4 \pm 2.2 \mathrm{~mm}, \mathrm{~N}=28)$ than those from Riofrío $(166.2 \pm 4.4 \mathrm{~mm}, \mathrm{~N}=17$; Mann-Whitney $\mathrm{U}$ test, $\mathrm{Z}=2.72, P=0.007$ ). No data were available for body size of hatchlings from the Matarranya River.

\section{DisCUSSION}

The use of growth marks of the ectopterygoid for age determination and their correlation with body size indicated sexual and interpopulation variation in growth trajectories in

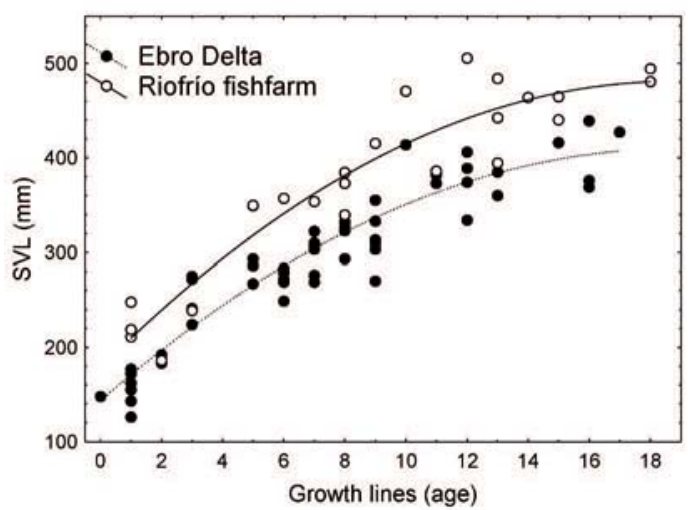

Figure 4: Relationship between age and body size (snout-vent length, SVL) for Natrix maura males in the Ebro Delta (closed circles and dotted line) and Riofrío (empty circles and solid line).
$N$. maura. With respect to interpopulation variation, we acknowledged that snakes and food availability at each population were collected in different years, and the causal linkage among food availability and growth trajectories must be interpreted with caution. The Mediterranean Basin is quite unpredictable year to year in climate and available food resources (BLONDEL et al., 2010), and annual variation in food resources could potentially modify snake's growth trajectories. However, two of the snake populations, the Ebro Delta and Riofrío, use food resources strongly controlled by humans because rice fields always follow a regular and constant cycle at the Ebro Delta (GONZÁLEZ-SOLÍs \& RUIZ, 1996), and fish production in Riofrío is constant throughout the year (A. Domezain, personal communication). These facts provide compelling evidence that collecting snakes in different years presumably do not affect growth interpopulation variation in growth trajectories. A second shortcoming of our study is that snakes from populations where potential prey are more abundant, may consume significantly more prey than those from populations with fewer trophic resources. There are several evidences that the percentage of $N$. maura individuals with recent prey in stomach varied with prey availability (RUGIERO et al., 2000; 
SANTOS et al., 2000), and we also found interpopulation differences in the proportion snakes with recent prey $(32.5 \%[\mathrm{~N}=40]$ at Matarranya, SANTOS et al., 2006; 13.4\% $[\mathrm{N}=343]$ at the Ebro Delta, SANTOS et al., 2000; 29.9\% [N = 97] at Riofrío, authors' unpublished data). At the Ebro Delta for instance, the percentage of individuals with recent prey varied monthly in parallel to the increase of food availability after the rice field flooding, and raised in May to $21.8 \%$, when availability was already high (SANTOS et al., 2000). Thereafter, the low availability of food at the Ebro Delta during part of the feeding period may obscure interpopulation differences in growth rates in $N$. maura; the differences exist, but may arise from different regimes of prey availability, from differences in the amount of prey availability, or from both factors. These shortcomings do not affect our finding of sexual variation at a single locality.

\section{Sexual variation in growth trajectories}

The relationship between estimated age and SVL fits a quadratic regression model in the three populations. This model assumes that snakes experience a period of rapid growth during two thirds of their lifespans, slowing down in the last third of their lives. In Matarranya and Riofrío however, the oldest females seemed to continue to grow and reach larger sizes, and this precluded calculation of asymptotic body size. This result was first reported by HAILEY \& DAVIES (1987a) for female $N$. maura in the Jalón River (eastern Spain), and suggests that large, older females, do not stop growing. The maximum age recorded by the ectopterygoid growth marks from the Matarranya River females, 22 years, evidences the long lifespan attained by some females. This is the oldest estimated age for $N$. maura, as the maximum age previously reported was 20 years for a female from the Jalón River (HAILEY \& DAVIES, 1987b). The lack of an asymptotic female body size is not the consequence of unlimited growth of $N$. maura, but the result of some females reaching a very large size, a phenomenon that is likely in dimorphic snake species in which females grow larger than males (SHINE, 1980).

The comparison of the slopes of the regression lines during the active growing period shows that female growth rate was higher than that of the males. Moreover, sexual differences in growth trajectories indicate that the age at which growth slows down in males and females varies by one year, happening earlier in males. Age and body size of sexual maturity also vary between sexes: males mature earlier and at smaller body size (2-3 years old, SVL 220-250 mm) than females (4-6 years old, SVL 312-350 mm; DuguY \& SAINT Girons, 1966; Hailey \& Davies, 1987a,c; Feriche \& Pleguezuelos, 1999; Santos \& Llorente, 2001). Sexual dimorphism in these traits may be related to the fecundity selection theory applied to snakes, because females are larger than males in those species where larger body sizes have been selected to favour the increase in abdominal cavity for accommodating larger clutches or litters (SHINE, 1993).

\section{Interpopulation variation in growth trajectories}

Interpopulation comparisons suggested that snakes in the Ebro Delta were younger and smaller than in the Matarranya River and Riofrío populations. Our results indicated slo- 
wer growth trajectories in the Ebro Delta population, this fact contributing to the smaller body size attained by these snakes. The interpopulation comparisons also showed that the asymptotic SVL of the growth curves in males were smaller in the Ebro Delta than in Riofrío. Similar results were obtained when comparing the Ebro Delta versus the Matarranya and Riofrío females. Although the slopes of the regression lines did not show significant interpopulation differences, the asymptotic point and the estimated annual growth rates did. Moreover at the Ebro Delta, the high proportion of snakes with the tail broken suggests a high predation pressure (SANTOS et al., 2011). These environmental conditions suggest that food availability and predation pressure may be concurrently acting to produce smaller $N$. maura at the Ebro Delta than at the other two populations.

What factors can account for these differences? Higher predation pressure at the Ebro Delta is caused by a high number of snake's predators (SANTOS et al., 2011). Differences in annual grow rates might be caused for interpopulation differences in the length of the feeding season, inferred by combining environmental temperatures and food availability. The monthly percentage of snakes with recent prey at the Ebro Delta (the only locality where these data were available) confirmed that snakes scarcely fed when rice fields were dry, whereas did when fields flooded up (SANTOS et al., 2000). Although there are not monthly values of the percentage of snakes with recent prey for Matarranya River and Riofrío, the comparison of the average values for the three populations $(13.4 \%, 32.5 \%$, and $29.9 \%$, for Ebro Delta, Matarranya and Riofrío, respectively) supports the reduced feeding opportunities of $N$. maura at the Ebro Delta. According to life-history theory, energy-demanding activities (e.g. maintenance, growth and reproduction) depend on an organism's feeding success (STEARNS, 1976). Some snakes have flexible strategies for adjusting the relative amount of energy allocated to body growth and storage in response to food availability (FORSMAN \& LiNDELL, 1996). Our findings indicate that snakes at the Ebro Delta experience a shorter feeding season compared to the Matarranya River and Riofrío populations. The Ebro Delta is a wetland area with high productivity rates (Forés \& COMín, 1992); however, restrictions in prey availability in this habitat are related to the rice-field irrigation system, which begins in April and ends in early autumn after rice harvesting. The rice-field cycle limits prey availability for $N$. maura, as fields and canals dry up from October to April, and aquatic prey become unavailable. Accordingly, snakes in the Ebro Delta have access to prey for 1-2 month less (on average) than snakes in the other two populations. On the contrary, we suggest that similarities in growth trajectories between the Matarranya and Riofrío snakes are primarily caused by a similar feeding season and presumably no limitation in food resources, as the Matarranya River has among the highest diversity and density of fish in Europe (DE SOSTOA, 2001) and Riofrío is a fish farm.

\section{Interpopulation differences in the size of hatchlings}

We found that the size of $N$. maura hatchling at the Ebro Delta was smaller than at Riofrío. Variation in the length of the feeding season experienced by each population may 
affect food-intake rates, which in turn may influence variation in hatchling size. In support of this explanation, SEIGEL \& FORD (2001) found that Thamnophis marcianus showed a marginal difference in neonate mass from females with access to higher prey availability. Moreover, SPARKMAN et al.(2007) showed that larger or older females had larger offspring, a result that fit our Ebro Delta-Riofrío comparison. Reproduction is energetically demanding, and consequently we would expect a trade-off between growth and reproductive output, especially where food availability is limited. In snakes, prey availability can affect reproductive output by limiting the number of females reproducing per year (SHINE \& MADSEN, 1997; Pleguezuelos et al., 2007), litter or clutch size (LOURDAIS et al., 2002), or offspring or hatchling body size or mass (FORD \& SeIGEL, 2011). Adult $N$. maura females reproduce every year throughout their range (SANTOS, 2004), and SANTOS et al. (2005) did not find any differences in clutch size (relative to female size) among the three populations studied here despite variation in the timing and duration of prey availability. Collectively, these findings suggest that clutch size (scaled for female size) is a fixed parameter within $N$. maura. Thus, our study found that $N$. maura's reproductive plasticity is manifested through hatchling size, and varies according to female food intake rates, which in turn may be determined by the duration of the period of prey availability (GREGORY \& LARSEN, 1993, 1996; SEIGEL \& ForD, 2001). Interpopulation differences in clutch and/or offspring size is based on the idea that local selective pressures are driving reproductive traits to maximize fitness on a particular geographic area (FORD \& SEIGEL, 2011). Most snakes are capital breeders and tend to gather resources over a long period prior to expending them during the short reproduction period (BONNET et al., 1994; NAULlEAU \& BONNET, 1996). Our study illustrates that intraspecific comparison among populations that experience different food regimes can exemplify the evolutionary strategies displayed by ectothermic organisms in energyallocation decisions.

\section{Acknowledgement}

We thank Genaro de Gamboa for his valuable mathematical support, Hernando Diaz and Ana María Diaz for their statistical comments, and to the blind testers Núria Garriga, Borja Ruiz and Guillem Pascual. We also thank Alberto Domezaín and the staff of the Riofrío fish farm for facilitating fieldwork. Research was carried out under hunting permits by the Direcció General del Medi Natural, Catalan Government (no. 6539, 26.10.1990 and no. 537, 29.01.1991) in the Ebro Delta, and by the Instituto para la Conservación de la Naturaleza (ICONA, Spanish Government) in the Matarranya River. Xavier Santos was supported by a post-doctoral grant (SFRH BPD/73176/2010) from Fundação para a Ciência e a Tecnologia (FCT, Portugal).

\section{REFERENCES}

ANDREWS, R.M. (1982). Patterns of growth in reptiles, In: C. Gans \& F.H. Pough (eds.). Biology of the Reptilia, vol. 13. Academic Press, New York, USA, pp. 273-320.

Aubret, F. \& Shine, R. (2007). Rapid preyinduced shift in body size in an isolated snake population (Notechis scutatus, Elapidae). Austral Ecology 32: 889-899. 
Aubret, F.; Shine, R. \& Bonnet, X. (2004). Adaptive developmental plasticity in snakes. Nature 431: 261-262.

Blondel, J.; Aronson, J.; Bodiou, J.-Y. \& Boeuf, G. (2010). The Mediterranean Region: Biological Diversity in Space and Time, $2^{\text {nd }}$ ed. Oxford University Press, Oxford, UK.

Bоваск, S. (2003). Body size evolution in snakes: evidence from island populations. Copeia 2003: 81-94.

Bohlin, T.; Hamrin, S.; HgGberget, T.G.; Rasmussen, G. \& Saltveit, S.V. (1989). Electrofishing: theory and practice with special emphasis on salmonids. Hydrobiologia 173: 9-43.

Bonnet, X.; Naulleau, G. \& Mauget, R. (1994). The influence of body condition on 17-b estradiol levels in relation to vitellogenesis in female Vipera aspis Reptilia, Viperidae. General and Comparative Endocrinology 93: 424-437.

Castanet, J.; Meunier, F. \& De RicQlès, A.

(1977). L'enregistrement de la croissance cyclique par le tissu osseux chez les vertébrés poikilotermes: données comparatives et essai de synthèse. Bulletin Biologique de la France et de la Belgique 111: 183-202.

Congdon, J.D.; Dunham, A.E. \& Tinkel, D.W. (1982). Energy budgets and life history of reptiles, In: C. Gans (ed.) Biology of Reptilia, vol. 13. Academic Press, New York, USA, pp. 233-271.

Congdon, J.D.; Dunham, A.E.; Hopkins, W.A.; Rowe, C.L. \& Hinton, T.C. (2001). Resource allocation-based life histories: a conceptual basis for studies of ecological toxicology. Environmental Toxicology and Chemistry 20: 1698-1703.

DE SostoA, A. (2001). Las comunidades de peces de las cuencas mediterráneas: caracte- rización y problemática, In I. Doadrio (ed.) Atlas y Libro Rojo de los Peces Continentales de España. Dirección General de Conservación de la Naturaleza, Madrid, Spain, pp. 51-56.

Duguy, R. \& Saint-Girons, H. (1966). Cycle annuel d'activité et reproduction de la couleuvre viperine Natrix maura (L.), d'après les notes manuscrites de Rollinat et des observations personnelles. La Terre et la Vie 4: 423-457.

DuRant, S.E.; Hopkins, W.A. \& TALENT, L.G. (2007). Energy acquisition and allocation in an ectothermic predator exposed to a common environmental stressor. Comparative Biochemistry and Physiology C 145: 442-448.

FALSTER, D.S., Warton, D.I. \& Wright, I.J. (2006). SMATR: Standardised major axis tests and routines, ver 2.0. Available at http://www.bio.mq.edu.au/ecology/SMATR/. Retrieved on 17 January 2014

FASOLA, M. (1986). Resource use of foraging herons in agricultural and nonagricultural habitats in Italy. Colonial Waterbirds 9: 139-148.

Feriche, M. \& Pleguezuelos, J.M. (1999). Características de la reproducción de la culebra viperina, Natrix maura (Linnaeus, 1758), en la Depresión de Granada (sureste ibérico). Revista Española de Herpetología 13: 37-48.

FORD, N.B. \& SEIGEL, R.A. (2011). Offspring size variation in snakes, In R.D. Aldridge \& D.M. Sever (eds.) Reproductive Biology and Phylogeny of Snakes. Series: Reproductive Biology and Phylogeny, vol. 9. Science Publisher, Enfield, New Hampshire, USA, pp. 573-586.

Forés, E. \& COMÍN, F.A. (1992). Ricefields, a limnological perspective. Limnetica 8: 101-109. 
ForSMAN, A. \& Lindell, L.E. (1991). Trade-off between growth and energy storage in male Vipera berus (L.) under different prey densities. Functional Ecology 5: 717-723.

Forsman, A. \& Lindell, L.E. (1996). Resource dependent growth and body condition dynamics in juvenile snakes: an experiment. Oecologia 108: 669-675.

GonZÁlez-Solís, J. \& Ruiz, X. (1996).

Succession and secondary production of gastropods in the Ebro Delta ricefields. Hydrobiologia 337: 85-92.

GonZÁlez-SOlís, J.; Bernardí, X. \& RuIZ, X. (1996). Seasonal variation of waterbird prey in the Ebro Delta rice fields. Colonial Waterbirds 19 (Special Publication 1): 135-142.

Gregory, P.T. \& Larsen, K.W. (1993). Geographic variation in reproductive characteristics among Canadian populations of the common garter snake (Thamnophis sirtalis). Copeia 1993: 946-958.

Gregory, P.T. \& LARSEN, K.W. (1996). Are there any meaningful correlates of geographic life-history variation in the garter snake Thamnophis sirtalis? Copeia 1996: 183-189.

Hailey, A. \& Davies, P.M.C. (1987a). Growth, movement and population dynamics of Natrix maura in a drying river. Herpetological Journal 1: 185-194.

Hailey, A. \& Davies, P.M.C. (1987b). Digestion, specific dynamic action, and ecological energetics of Natrix maura. Herpetological Journal 1: 159-166.

Hailey, A. \& Davies, P.M.C. (1987c). Maturity, mating and age-specific reproductive effort of the snake Natrix maura. Journal of Zoology 211: 573-587.

Hailey, A.; Davies, P.M.C. \& Pulford, E. (1982). Lifestyle and thermal ecology of natricine snakes. British Journal of Herpetology 6: 261-268.

JaÉn, M.J. \& PÉReZ-Mellado, V. (1989). Temperaturas corporales y ritmos de actividad en una población de Natrix maura (L.) del Sistema Central. Doñana Acta Vertebrata 16: 203-217.

Lessells, C. (1991). The evolution of life histories, In: J.R. Krebs \& N.B. Davies (eds.) Behavioural Ecology. Blackwell, Oxford, UK, pp. 32-68.

Lourdais, O.; Bonnet, X.; ShINe, R.; Denardo, D.; Naulleau, G. \& Guillon, M. (2002). Capital-breeding and reproductive effort in a variable environment: a longitudinal study of a viviparous snake. Journal of Animal Ecology 71: 470-479.

Madsen, T. \& Shine, R. (1993). Phenotypic plasticity in body sizes and sexual dimorphism in European grass snakes. Evolution 47: 321-325.

MALKMUS, R. (2008). Winteraktive Schlangen in Portugal (Erganzende Bemerkungen). Zeitschrift fur Feldherpetologie 15: 97-98.

MATHWORKS (1996). MATLAB. The Language of Technical computing. Version 7. The MathWorks, Inc. Available at http:// www.mathworks.com. Retrieved on 17 January 2014.

McNaB, B.K. (2002). The Physiological Ecology of Vertebrates: a View from Energetics. Cornell University Press, Ithaca, New York, USA.

Naulleau, G. \& Bonnet, X. (1996). Body condition threshold for breeding in a viviparous snake. Oecologia 107: 301-306.

O'STEEN, S. (1998). Embryonic temperature influences juvenile temperature choice and growth rate in snapping turtles Chelydra serpentina. Journal of Experimental Biology 201: 439-449. 
Peabody, F.E. (1961). Annual growth zones in vertebrates (living and fossil). Journal of Morphology 108: 11-62.

Pleguezuelos, J.M.; Santos, X.; Brito, J.C.; Parellada, X.; Llorente, G.A. \& FAHD, S. (2007). Reproductive ecology of Vipera latastei in the Iberian Peninsula: implications for the conservation of a Mediterranean viper. Zoology 110: 9-19.

ReZnicK, D.A.; Bryga, H. \& ENDler, J.A. (1990). Experimentally induced life-history evolution in a natural population. Nature 346: 357-359.

Rugiero, L.; Capula, M.; Persichetti, D.; Luiselli, L. \& Angelici, F.M. (2000). Life-history and diet of two populations of Natrix maura (Reptilia, Colubridae) from contrasted habitats in Sardinia. Miscelanea Zoologica 23: 41-51.

SANTOS, X. (2004). Culebra viperina. Natrix maura, In A. Salvador \& A. Marco (eds.) Enciclopedia Virtual de los Vertebrados Españoles. Museo Nacional de Ciencias Naturales, Madrid, Spain. Available athttp://www.vertebradosibericos.org/. Retrieved on 11/22/2013.

SAntos, X. \& Llorente G.A. (1998). Sexual and size-related differences in the diet of the snake Natrix maura from the Ebro Delta, Spain. Herpetological Journal 8: 161-165.

SAntos, X. \& Llorente, G.A. (2001). Seasonal variation in reproductive traits of the oviparous water snake, Natrix maura, in the Ebro Delta of Northeastern Spain. Journal of Herpetology 35: 653-660.

SAnTOS, X. \& LlORENTE, G.A. (2004). Lipid dynamics in the viperine snake, Natrix maura, from the Ebro Delta (NE Spain). Oikos 105: 132-140.

SANTOS, X., GonZÁleZ-Solís, J. \& Llorente,
G.A. (2000). Variation in the diet of the viperine snake Natrix maura in relation to prey availability. Ecography 23: 185-192.

Santos, X.; Llorente, G.A.; Feriche, M.; Pleguezuelos, J.M.; Casals, F. \& DE SostoA, A. (2005). Food availability induces geographic variation in reproductive timing of an aquatic oviparous snake (Natrix maura). Amphibia-Reptilia 26: 183-191.

Santos, X.; Vilardebó, E.; Casals, F.; Llorente, G.A.; Vinyoles, D. \& DE SostoA, A. (2006). Wide food availability favours intraspecific trophic segregation in predators: the case of a water snake in a Mediterranean river. Animal Biology 56: 299-309.

Santos, X.; Arenas, C.; Llorente, G.A. \& RuIZ, X. (2007). Exploring the origin of egg protein in an oviparous water snake (Natrix maura). Comparative Biochemistry and Physiology A 147: 165-172.

SANTOS, X.; Feriche, M.; LeÓN, R.; FilippaKopoulou, A.; Vidal-García, M.; Llorente, G.A. \& Pleguezuelos, J.M. (2011). Tail breakage frequency as an indicator of predator risk for the aquatic snake Natrix maura. Amphibia-Reptilia 32: 375-383.

SeIGEL, R.A. \& FORD, N.B. (2001). Phenotypic plasticity in reproductive traits: geographical variation in plasticity in a viviparous snake. Functional Ecology 15: 36-42.

SHINE, R. (1980). Cost of reproduction in reptiles. Oecologia 46: 92-100.

Shine, R. (1993). Australian Snakes. A Natural History. Reed Books, Chatswood, New South Wales, Australia.

SHINE, R. (2003). Reproductive strategies in snakes. Proceedings of the Royal Society B: Biological Sciences 270: 995-1004. 
Shine, R. \& Madsen, T. (1997). Prey abundance and predator reproduction: rats and pythons on a tropical Australian floodplain. Ecology 78: 1078-1086.

Shine, R.; Reed, R.N.; Shetty, S. \& Cogger, H.G. (2002). Relationship between sexual dimorphism and niche partitioning within a clade of sea-snakes (Laticaudinae). Oecologia 133: 45-53.

SPARKMAN, A.M.; ARnold, S.J. \& BRONIKOWsKI, A.M. (2007). An empirical test of evolutionary theories for reproductive senescence and reproductive effort in the garter snake Thamnophis elegans. Proceedings of the Royal Society B: Biological Sciences 274: 943-950.

STATSOFT (2007). STATISTICA (data analysis software system), version 8.0. StatSoft Inc. Available at http://www.statsoft.com. Retrieved on 17 January 2014.
STEARNS, S.C. (1976). Life-history tactics: a review of the ideas. Quarterly Review of Biology 51: 3-47.

STEARNS, S.C. (1989). Trade off in life history evolution. Functional Ecology 3: 259-268.

STEARNS, S.C. (1992). The Evolution of Life Histories. Oxford University Press, New York, USA.

WAye, H.L. \& Gregory, P.T. (1998). Determining the age of garter snakes (Thamnophis spp.) by means of skeletochronology. Canadian Journal of Zoology 76: 288-294.

White, G.C.; Burnham, K.P.; Otis, D.L. \& ANDERSON, D.R. (1978). User's Manual for Program CAPTURE. Utah State University Press, Logan, Utah, USA.

ZipPIN, C. (1958). The removal method of population estimation. Journal of Wildlife Management 22: 82-90. 